\title{
A test of altitude-related variation in aerobic metabolism of Andean birds
}

Gutierrez-Pinto, Natalia $^{1}{ }^{*}$, Gustavo A. Londoño ${ }^{2}$, Mark A. Chappell ${ }^{3}$, and Jay F. Storz ${ }^{1}$

1. School of Biological Sciences, University of Nebraska, Lincoln, NE 68588, USA

2. Departamento de Ciencias Biológicas, Facultad de Ciencias Naturales, Universidad Icesi, Cali, Colombia

3. Department of Evolution, Ecology, and Organismal Biology, University of California, Riverside, CA 92521, USA

*corresponding author: gutinata@gmail.com

\section{Submitted to Journal of Experimental Biology}




\title{
Summary statement
}

We tested for altitude-related variation in aerobic metabolism in species pairs with contrasting elevational ranges. Metabolic rates were significantly higher in most highland species but there was no uniform elevational trend.

\author{
Abstract \\ Endotherms at high altitude face the combined challenges of cold and hypoxia. Cold increases \\ thermoregulatory costs, and hypoxia may limit both thermogenesis and aerobic exercise \\ capacity. Consequently, in comparisons between closely related highland and lowland taxa, we \\ might expect to observe consistent differences in basal metabolism (BMR), maximal \\ metabolism (MMR), and aerobic scope. Broad-scale comparative studies of birds reveal no \\ association between BMR and native elevation, and altitude effects on MMR have not been \\ investigated. We tested for altitude-related variation in aerobic metabolism in 10 Andean \\ passerines representing five pairs of closely related species with contrasting elevational ranges. \\ Mass-corrected BMR and MMR were significantly higher in most highland species relative to \\ their lowland counterparts, but there was no uniform elevational trend across all pairs of \\ species.
}




\section{Introduction}

Endotherms that are native to high-altitude environments must contend with physiological challenges posed by the reduced partial pressure of $\mathrm{O}_{2}\left(P \mathrm{O}_{2}\right)$ and low ambient temperature $\left(\mathrm{T}_{\mathrm{a}}\right)$. Depending on acclimatization history, reduced $\mathrm{PO}_{2}$ may compromise the maximum capacities for aerobic exercise (MMR; maximum metabolic rate) due to the reduced availability of $\mathrm{O}_{2}$ to fuel ATP synthesis (Chappell et al., 2007; Hayes, 1989a; McClelland and Scott, 2019; Storz and Scott, 2019; Storz et al., 2010). BMR may be elevated in highland species due to increased thermoregulatory demands or due to a correlated response to changes in MMR (Hayes and Garland, 1995; Portugal et al., 2016; Rezende et al., 2004). Non-proportional changes in BMR and MMR entail changes in absolute aerobic scope, defined as the difference between the two rates (MMR - BMR), which reflects an animal's capacity to increase its rate of aerobic metabolism above maintenance levels (Bennett, 1991; Hochachka, 1985).

In comparison with lowland relatives, mammals native to high-altitude often have higher mean MMR in hypoxia and suffer a smaller decrement in MMR with increasing hypoxia (Chappell and Dlugosz, 2009; Cheviron et al., 2012; Cheviron et al., 2014; Lau et al., 2017; Lui et al., 2015; Schippers et al., 2012; Storz et al., 2019; Tate et al., 2017; Tate et al., 2020). In addition, when measured at their native elevations, BMR is consistently higher in high-altitude deer mice (Peromyscus maniculatus) relative to lowland conspecifics (Hayes, 1989a; Hayes, 1989b), although it is not known to what extent the elevated BMR reflects an evolved change or a reversible acclimatization response. Available evidence for birds suggests that BMR does not vary with elevation, and it is unknown whether MMR exhibits a consistent pattern of altitudinal variation among species.

Studies of highland and lowland populations of rufous-collared sparrows (Zonotrichia capensis), measured at their native altitudes, found no differences in BMR (Castro et al., 1985), thermogenic capacity (Novoa et al., 1990), or field metabolic rates (Novoa et al., 1991). A recent study involving a phylogenetically diverse set of more than 250 neotropical bird species found 
no significant association between BMR and native elevation (Londoño et al., 2015). However, altitude effects may be more readily detectable in fine-grained comparisons between pairs of closely related species that are native to different elevations but that are otherwise ecologically similar. Moreover, it remains unclear if exercise-induced MMR and aerobic scope exhibit consistent patterns of altitude variation.

We measured BMR, MMR, and aerobic scope in 10 Andean passerines, representing five pairs of closely related species with contrasting elevational ranges (Figure 1A, B). We used a pairedlineage design (Felsenstein, 2004) such that the five pairwise comparisons were phylogenetically independent (Figure 1A). 


\section{Materials and Methods}

\section{Experimental design}

Birds were captured between June and August from 2017 to 2019 at several field sites in the western Andes of Colombia (figure 1A; supplementary Table 1). We compared closely related species that had contrasting elevation ranges (figure 1B) but which are otherwise similar

ecologically (supplementary table 2). High elevation species were captured between 2300 and $2500 \mathrm{~m}$; low elevation species were captured between 500 and $1400 \mathrm{~m}$. Annual mean temperature differed between localities by approximately $6^{\circ} \mathrm{C}$ and ambient $\mathrm{pO}_{2}$ differed by 1.9 $4.5 \mathrm{kPa}$ (mean $3 \mathrm{kPa})$.

\section{Field protocol}

We mist-netted birds (aided by playback of vocalizations) during the day (9:00 to 18:00 h). We released juveniles (identified on the basis of plumage or color of bill gape) and adults with brood patches. We measured MMR immediately after capture and subsequently kept birds inside cloth bags, taking them out every two hours to provide water and food, until 4 hours before the onset of BMR measurements (after sunset, around 19:00h), to ensure that the birds were post-absorptive (Karasov and del Rio, 2007). Body mass was measured immediately after capture and also before and after BMR measurements. All procedures were approved by the University of Nebraska IACUC (project ID 1499) and Colombian research permits granted to G.A.L. (Permit 536, May 20/2016).

\section{Respirometry procedures}

We used a flow-through respirometry system to measure metabolic rates. Incurrent air was dried with silica gel and the flow was then divided into four metered channels using a FlowBar (Sable Systems, Las Vegas, NV, USA). One channel was used for reference air. The other three supplied air continuously to three metabolic chambers made of acrylic, each equipped with a 
thermocouple that measured excurrent air temperature. Another thermocouple measured $\mathrm{T}_{\mathrm{a}}$ in the incubator. We measured one to three birds per night and matched incurrent airflow into chambers with the body mass of each tested bird (200-1000 $\mathrm{mL} \mathrm{min}^{-1}$ STPD). Excurrent air flows were sampled sequentially by a multiplexer (Sable Systems RM-8). Subsamples of excurrent airflow (50-200 mL min ${ }^{-1}$ ) were scrubbed of $\mathrm{CO}_{2}$ and $\mathrm{H}_{2} \mathrm{O}$ (using soda lime and silica gel, respectively) and routed through a Sable Systems FoxBox to measure $\mathrm{O}_{2}$ content. Each bird was monitored for $15 \mathrm{~min}$ and reference air was measured for $2.5 \mathrm{~min}$ before switching between individuals; this pattern was repeated until the measurements were finished. $T_{a}$ was kept constant $\left( \pm 0.5^{\circ} \mathrm{C}\right)$ using a PELT -5 controller (Sable Systems). Birds were first measured at $\mathrm{T}_{\mathrm{a}}$ $=34^{\circ} \mathrm{C}$ and then at $\mathrm{T}_{\mathrm{a}}=30^{\circ} \mathrm{C}$, remaining at each stable temperature for at least one hour. We recorded $\mathrm{T}_{a}$, flow rate and $\mathrm{O}_{2}$ content every second using Warthog LabHelper (www.warthog.ucr.edu) interfaced to a Sable UI-2 A-D converter.

We elicited MMR using forced exercise on a hop-flutter wheel (Chappell et al., 1999). This method reliably elicits behavioral exhaustion, with repeatable MMR (Chappell et al., 1996), but may not elicit maximum power output of the flight muscles. Accordingly, $\mathrm{VO}_{2}$ values measured with this technique are usually lower than those measured in wind tunnels (Chappell et al., 2011; McKechnie and Swanson, 2010). During exercise trials, incurrent air flow was 750 - 1000 $\mathrm{mL} \mathrm{min}^{-1}$, and no multiplexer was used. The chamber was manually rotated until birds reached their maximum rates of oxygen consumption, typically at the beginning of the experiment. All tested birds attained similar levels of behavioral exhaustion during the exercise trials and no birds were injured during experiments.

\section{Data analysis}

We calculated metabolic rates using LabAnalyst (www.warthog.ucr.edu). After baseline correction, we used the flow rate (FR; $\left.\mathrm{mL} \mathrm{min}^{-1} \mathrm{STPD}\right)$, and the incurrent $\left(\mathrm{FiO}_{2} ; 0.2095\right)$ and excurrent $\left(\mathrm{FeO}_{2}\right)$ oxygen concentrations to obtain $\mathrm{VO}_{2}\left(\mathrm{~mL} \mathrm{O}_{2} \mathrm{~min}^{-1}\right)$, applying the 'Mode 1' formula: 


$$
V \mathrm{O}_{2}=\mathrm{FR}\left(\mathrm{FiO}_{2}-\mathrm{FeO}_{2}\right) /\left(1-\mathrm{FeO}_{2}\right)
$$

BMR was computed as the lowest continuous average $\mathrm{VO}_{2}$ over 5 min during periods of low and stable $\mathrm{VO}_{2}$, and the lowest value of the two temperature measurements per bird $\left(30\right.$ and $\left.34{ }^{\circ} \mathrm{C}\right)$ was chosen for subsequent analyses. Before obtaining $M M R\left(\mathrm{VO}_{2 \max }\right)$, we applied the instantaneous correction (Bartholomew et al., 1981) to compensate for the mixing characteristics of the system (i.e., the blunted response to rapid changes in $\mathrm{O}_{2}$ concentration). We calculated MMR as the highest continuous averaged $\mathrm{VO}_{2}$ over 1 minute during periods of high and stable $\mathrm{VO}_{2}$ values. Finally, we calculated the absolute aerobic scope for each bird as the difference between MMR and BMR.

\section{Statistics}

We used log-transformed metabolic rates in interspecific comparisons and we included logtransformed body mass as a covariate in the analyses. For each species and metabolic measurement, we discarded data points that fell outside \pm 2 standard deviations from the mean, resulting in the removal of two data points for BMR, six for MMR, and five for aerobic scope.

To evaluate whether the allometric association between mass and $\mathrm{VO}_{2}$ differed between closely related species, we tried fitting standardized major axis (SMA) regressions between mass and $\mathrm{VO}_{2}$ for each species using the smatr package (Warton et al., 2012) for R v. 3.3.2 (R Core Team, 2012). Since most of the regressions were not significant (results not shown), we followed two different approaches to evaluate the influence of body mass on measured metabolic rates. First, we adjusted linear models to account for the joint influences of elevation and mass on $\mathrm{VO}_{2}$. For this, we fitted a linear mixed model (package Ime4; Bates et al., 2014) with $\mathrm{VO}_{2}$ as the response variable, elevation (categorical; 1 for high elevation, 2 for low elevation) as a fixed effect, and mass (continuous) per species pair (categorical; 5 levels) as a random effect: 


$$
\mathrm{VO}_{2} \sim \text { elevation }+ \text { (mass | species pair) }
$$

This model allows the slope of the relationship between mass and $\mathrm{VO}_{2}$ to be different for each species group. To further explore whether the effect of elevation differs between species pairs after accounting for mass, we also ran a nested ANCOVA, where the variation in $\mathrm{VO}_{2}$ is explained by mass and by elevation per group:

$$
\mathrm{VO}_{2} \sim \text { mass }+ \text { (species pair : elevation) }
$$

Second, in order to better understand the trends observed in the linear models, we masscorrected each of our observed $\mathrm{VO}_{2}$ values (BMR, MMR, aerobic scope) by dividing them by $\mathrm{M}_{b}{ }^{\mathrm{S}}$ (Gillooly et al., 2001), where $M_{b}$ is body mass for each individual and $S$ is the allometric scaling coefficient obtained by McKechnie and Wolf (2004) for passerine birds ( $S=0.667)$. We then used $t$-tests to evaluate the statistical significance of the difference in mass-corrected $\mathrm{VO}_{2}$ between high- and low-elevation species within each pair. We also ran a post-hoc power analysis (package pwr v1.3; Champely, 2020) using Hedges' G (Hedges, 1983) to estimate effect sizes with a significance level of 0.05 .

Finally, to assess the influence of other variables on metabolic rates, we built linear mixed models that included various combinations of mass and the interaction between species group (categorical; 5 levels) and elevation (categorical; high, low) as fixed factors, and age (categorical; immature, adult), sex (categorical; male, female), molt state (categorical; absent if bird had no developing feathers, moderate if few, abundant if several), and year of capture $(2017,2018,2019)$ as random factors. In all mixed effect models the variance explained by any variable other than mass was negligible (usually $<<0.1$ ), and the model that included mass as the only predictor had the lowest $\operatorname{AIC}(\triangle \mathrm{AIC}=46$; results not shown). 


\section{Results and Discussion}

We measured 96 wild-caught birds, with sample sizes of 8-12 individuals per species (Figure 2; supplementary table 3), except for Turdus serranus ( $n=4)$. Both the linear mixed model and the ANCOVA explained a high percentage of variation in the data (average $\mathrm{R}^{2}$ for mixed model: 0.98; average adjusted $R^{2}$ for ANCOVA: 0.69; supplementary tables 4 and 5). Elevation was correlated with BMR, MMR, and aerobic scope, but only after accounting for the effects of species pair and body mass, as evidenced by the difference between the average marginal $\mathrm{R}^{2}$ (0.006; variance explained by the fixed effect) and the average conditional $R^{2}$ (0.98; variance explained by the full model) (supplementary table 4). Likewise, after accounting for mass, elevation also had a significant effect on variation in BMR, MMR, and aerobic scope in each species pair (supplementary table 5), with the exception of BMR in thrushes. In all species pairs other than thrushes, high-elevation species had higher metabolic rates than their lowland counterparts, as indicated by the negative slopes estimated for the effect of elevation on each species group (supplementary table 5).

Our pairwise comparisons of mass-corrected metabolic rates revealed significant differences between high- and low- elevation species in most but not all cases. BMR was significantly higher in high-elevation wrens, tanagers, and warblers (Figure 3, left; supplementary table 3), MMR was significantly higher for high-elevation wrens, tanagers and warblers (Figure 3, middle), and aerobic scope was significantly higher for high-elevation thrushes, tanagers, and warblers (Figure 3, right). Spinetails did not exhibit significant elevational differences in BMR, MMR, or aerobic scope.

In our small sample of Andean passerines, we found a significant effect of elevation on BMR, MMR, and aerobic scope after accounting for effects of body mass (supplementary tables 3, 4, and 5). In most cases, high-elevation species had higher BMR and MMR than closely related and ecologically similar low-elevation species. Overall, we observed significant differences in rates of aerobic metabolism between individual pairs of species, but we did not document a 
uniformly consistent elevational trend. Our study and most others to date have investigated elevational variation in aerobic metabolism by measuring wild-caught birds in their native habitat (e.g. Jones et al., 2020; Londoño et al., 2015; Londoño et al., 2017). In the future, common-garden or reciprocal-transplant experiments that control for acclimatization effects should help reveal whether bird species native to high elevations have generally evolved increased aerobic performance capacities in cold, hypoxic conditions. 


\section{Acknowledgements}

We wish to thank all the students whose invaluable help in the field made this project possible, especially to Jorge Lizarazo, Isabel Cifuentes, Valentina Echeverry, Jose Riascos, and Maria Laura Mahecha. For facilitating logistics at fieldwork sites in Colombia we thank the staff at ICESI University, staff at CELSIA, Alirio Bolivar, Ana Tulia Montes, and Gustavo Giraldo. Additional help with fieldwork preparation was provided by Andrew Crawford and Santiago Herrera. Gwen Bachman offered vital guidance while processing metabolic rate data. We are thankful with Kate Lyons, John DeLong, Graham Scott, and Grant McClelland for discussions and assistance with the statistical analyses. Finally, this work greatly benefited from discussions with Gwen Bachman, Chris Witt, Kristi Montooth, Colin Meiklejohn, and Jamilynn Poletto.

\section{Competing interests}

The authors declare no competing or financial interests.

\section{Author contributions}

Conceptualization: N.G.P., J.F.S.; Methodology: N.G.P., J.F.S.; Formal analysis: N.G.P.; Investigation: N.G.P.; Data curation: N.G.P.; Writing - original draft: N.G.P.; Writing - review \& editing: N.G.P, G.A.L., M.A.C., J.F.S.; Supervision: G.A.L., J.F.S.; Funding acquisition: N.G.P, G.A.L., J.F.S.

\section{Funding}

This research was supported by grants from the National Institutes of Health (HLO87216) and the National Science Foundation (OIA-1736249 and IOS-1927675) to J. F. S.; R. C. Lewontin Graduate Research Excellence Grant and University of Nebraska SBS Special Funds to N. G. P.; and the research agreement between Icesi University and EPSA-Celsia singed in 2016 to G. A. L. 
bioRxiv preprint doi: https://doi.org/10.1101/2020.10.01.310128; this version posted October 3, 2020. The copyright holder for this preprint (which was not certified by peer review) is the author/funder. All rights reserved. No reuse allowed without permission. 


\section{Figure legends}

Figure 1. A. Phylogenetic relationships among the ten study species. Terminal branches (in black) connect pairs of high- and low-elevation species. Branch lengths are proportional to estimated divergence times (Barker et al., 2015; Batista et al., 2020; Cadena et al., 2019; Derryberry et al., 2011) B. Approximate elevational distribution of the study species in the northern Andes (Hilty and Brown, 1986). White circles represent the elevation at which measurements were made for each species (see supplementary table 1). Illustrations from Ayerbe-Quiñones (2018).

Figure 2. Relationships between mass and BMR (top row), MMR (middle row), and absolute aerobic scope (AAS; bottom row) for each pair of high- and low-elevation species. SMA regression lines are shown in cases where the tested association was statistically significant. In each pair, high elevation species are shown in light blue and low elevation species in dark blue. Boxplots depict the variation for each species in metabolic rate (left) and mass (bottom).

Figure 3. Mass-corrected values $\left(\mathrm{ml} \mathrm{O}_{2} \mathrm{~min}^{-1} \mathrm{~g}^{-1}\right.$ ) for $\mathrm{BMR}$ (top), MMR (middle), and absolute aerobic scope (AAS; bottom) of Andean passerines. Alternating light grey and white columns denote the species pairs being compared; within each pair, light and dark blue boxes represent high and low elevation species, respectively. Three significance levels of the pairwise $t$-tests comparing mass-corrected metabolic values between high- and low- elevation species are indicated on top of each graph: non-significance (n.s; $p>0.05), p<0.05\left({ }^{*}\right)$, and $p<0.01\left({ }^{* *}\right)$; $p$ values and differences in group means can be found in supplementary table 3. 


\section{Literature cited}

Ayerbe-Quiñones, F. (2018). Guía ilustrada de la avifauna colombiana. Wildlife Conservation Society, Bogotá, Colombia.

Barker, F. K., Burns, K. J., Klicka, J., Lanyon, S. M. and Lovette, I. J. (2015). New insights into New World biogeography: An integrated view from the phylogeny of blackbirds, cardinals, sparrows, tanagers, warblers, and allies. The Auk 132, 333-348.

Bartholomew, G. A., Vleck, D. and Vleck, C. M. (1981). Instantaneous measurements of oxygen consumption during pre-flight warm-up and post-flight cooling in sphingid and saturniid moths. Journal of Experimental Biology 90, 17-32.

Bates, D., Mächler, M., Bolker, B. and Walker, S. (2014). Fitting linear mixed-effects models using Ime4. Journal of Statistical Software 67, 1-48.

Batista, R., Olsson, U., Andermann, T., Aleixo, A., Ribas, C. C. and Antonelli, A. (2020). Phylogenomics and biogeography of the world's thrushes (Aves, Turdus): new evidence for a more parsimonious evolutionary history. Proceedings of the Royal Society B: Biological Sciences 287, 20192400.

Bennett, A. F. (1991). The evolution of activity capacity. Journal of Experimental Biology $160,1-23$.

\section{Cadena, C. D., Pérez-emán, J. L., Cuervo, A. M., Céspedes, L. N., Epperly, K. L. and} Klicka, J. T. (2019). Extreme genetic structure and dynamic range evolution in a montane passerine bird: implications for tropical diversification. Biological Journal of the Linnean Society 126, 487-506.

Castro, G., Carey, C., Whittembury, J. and Monge, C. (1985). Comparative responses of sea level and montane rufous-collared sparrows, Zonotrichia capensis, to hypoxia and cold. Comparative Biochemistry and Physiology Part A: Physiology 82, 847-850.

Champely, S. (2020). pwr: Basic Functions for Power Analysis. In R package

Chappell, M. A., Bech, C. and Buttemer, W. A. (1999). The relationship of central and peripheral organ masses to aerobic performance variation in house sparrows. The Journal of Experimental Biology 202, 2269-2279. 
Chappell, M. A. and Dlugosz, E. M. (2009). Aerobic capacity and running performance across a $1.6 \mathrm{~km}$ altitude difference in two sciurid rodents. Journal of Experimental Biology 212, 610-619.

Chappell, M. A., Hammond, K. A., Cardullo, R. A., Russell, G. A., Rezende, E. L. and Miller, C. (2007). Deer mouse aerobic performance across altitudes: effects of developmental history and temperature acclimation. Physiological and Biochemical Zoology 80, 652-662.

Chappell, M. A., Savard, J.-F., Siani, J., Coleman, S. W., Keagy, J. and Borgia, G. (2011). Aerobic capacity in wild satin bowerbirds: repeatability and effects of age, sex and condition. Journal of Experimental Biology 214, 3186-3196.

Chappell, M. A., Zuk, M. and Johnsen, T. S. (1996). Repeatability of Aerobic Performance in Red Junglefowl: Effects of Ontogeny and Nematode Infection. Functional Ecology 10, 578-585.

Cheviron, Z. A., Bachman, G. C., Connaty, A. D., McClelland, G. B. and Storz, J. F. (2012). Regulatory changes contribute to the adaptive enhancement of thermogenic capacity in high-altitude deer mice. Proceedings of the National Academy of Sciences 109, 8635-8640.

Cheviron, Z. A., Connaty, A. D., McClelland, G. B. and Storz, J. F. (2014). Functional genomics of adaptation to hypoxic cold-stress in high-altitude deer mice: transcriptomic plasticity and thermogenic performance. Evolution 68, 48-62.

Derryberry, E. P., Claramunt, S., Derryberry, G., Chesser, R. T., Cracraft, J., Aleixo, A., Pérez-Emán, J., Remsen Jr, J. and Brumfield, R. T. (2011). Lineage diversification and morphological evolution in a large-scale continental radiation: the neotropical ovenbirds and woodcreepers (Aves: Furnariidae). Evolution 65, 2973-2986.

Felsenstein, J. (2004). Inferring Phylogenies. Sunderland, MA: Sinauer Associates, Inc.

Gillooly, J. F., Brown, J. H., West, G. B., Savage, V. M. and Charnov, E. L. (2001). Effects of Size and Temperature on Metabolic Rate. Science 293, 2248-2251.

Hayes, J. P. (1989a). Altitudinal and seasonal effects on aerobic metabolism of deer mice. Journal of Comparative Physiology B 159, 453-459.

Hayes, J. P. (1989b). Field and maximal metabolic rates of deer mice (Peromyscus maniculatus) at low and high altitudes. Physiological Zoology 62, 732-744. 
Hayes, J. P. and Garland Jr, T. (1995). The evolution of endothermy: testing the aerobic capacity model. Evolution 49, 836-847.

Hedges, L. V. (1983). A random effects model for effect sizes. Psychological Bulletin 93, 388-395.

Hilty, S. L. and Brown, W. L. (1986). A Guide to the Birds of Colombia. Princeton: Princeton University Press.

Hochachka, P. (1985). Exercise limitations at high altitude: the metabolic problem and search for its solution. In Circulation, respiration, and metabolism, pp. 240-249: Springer.

Jones, S. E. I., Suanjak, M., Tobias, J. A., Freeman, R. and Portugal, S. J. (2020). Comparative physiology of five tropical montane songbirds reveals differential seasonal acclimatisation and cold adaption. bioRxiv, 2020.05.22.111328.

Karasov, W. H. and del Rio, C. M. (2007). Physiological ecology: how animals process energy, nutrients, and toxins: Princeton University Press.

Lau, D. S., Connaty, A. D., Mahalingam, S., Wall, N., Cheviron, Z. A., Storz, J. F., Scott, G. R. and McClelland, G. B. (2017). Acclimation to hypoxia increases carbohydrate use during exercise in high-altitude deer mice. American Journal of Physiology-Regulatory, Integrative and Comparative Physiology.

Londoño, G. A., Chappell, M. A., Castañeda, M. d. R., Jankowski, J. E. and Robinson, S. K. (2015). Basal metabolism in tropical birds: latitude, altitude, and the 'pace of life'. Functional Ecology 29, 338-346.

Londoño, G. A., Chappell, M. A., Jankowski, J. E. and Robinson, S. K. (2017). Do thermoregulatory costs limit altitude distributions of Andean forest birds? Functional Ecology 31, 204-215.

Lui, M. A., Mahalingam, S., Patel, P., Connaty, A. D., Ivy, C. M., Cheviron, Z. A., Storz, J. F., McClelland, G. B. and Scott, G. R. (2015). High-altitude ancestry and hypoxia acclimation have distinct effects on exercise capacity and muscle phenotype in deer mice. American Journal of Physiology-Regulatory, Integrative and Comparative Physiology 308, R779-R791.

McClelland, G. B. and Scott, G. R. (2019). Evolved mechanisms of aerobic performance and hypoxia resistance in high-altitude natives. Annual Review of Physiology 81, 561-583. 
McKechnie, A. E. and Swanson, D. L. (2010). Sources and significance of variation in basal, summit and maximal metabolic rates in birds. Current Zoology 56, 741-758.

McKechnie, A. E. and Wolf, B. O. (2004). The allometry of avian basal metabolic rate: good predictions need good data. Physiological and Biochemical Zoology 77, 502-521.

Novoa, F. F., Bozinovic, F. and Rosenmann, M. (1990). Maximum metabolic rate and temperature regulation in the rufous-collared sparrow, Zonotrichia capensis, from central chile. Comparative Biochemistry and Physiology Part A: Physiology 95, 181-183.

Novoa, F. F., Rosenmann, M. and Bozinovic, F. (1991). Physiological responses of four passerine species to simulated altitudes. Comparative Biochemistry and Physiology Part A: Physiology 99, 179-183.

Portugal, S. J., Green, J. A., Halsey, L. G., Arnold, W., Careau, V., Dann, P., Frappell, P. B., Grémillet, D., Handrich, Y. and Martin, G. R. (2016). Associations between resting, activity, and daily metabolic rate in free-living endotherms: no universal rule in birds and mammals. Physiological and Biochemical Zoology 89, 251-261.

Rezende, E. L., Bozinovic, F., Garland, T. and Merilä, J. (2004). Climatic adaptation and the evolution of basal and maximum rates of metabolism in rodents. Evolution 58, 1361-1374.

Schippers, M.-P., Ramirez, O., Arana, M., Pinedo-Bernal, P. and McClelland, Grant B. (2012). Increase in Carbohydrate Utilization in High-Altitude Andean Mice. Current Biology 22, 2350-2354.

Storz, J. F., Cheviron, Z. A., McClelland, G. B. and Scott, G. R. (2019). Evolution of physiological performance capacities and environmental adaptation: insights from highelevation deer mice (Peromyscus maniculatus). Journal of Mammalogy 100, 910-922.

Storz, J. F. and Scott, G. R. (2019). Life Ascending: Mechanism and Process in Physiological Adaptation to High-Altitude Hypoxia. Annual Review of Ecology, Evolution, and Systematics.

Storz, J. F., Scott, G. R. and Cheviron, Z. A. (2010). Phenotypic plasticity and genetic adaptation to high-altitude hypoxia in vertebrates. The Journal of Experimental Biology 213, 4125-4136. 
Tate, K. B., Ivy, C. M., Velotta, J. P., Storz, J. F., McClelland, G. B., Cheviron, Z. A. and Scott, G. R. (2017). Circulatory mechanisms underlying adaptive increases in thermogenic capacity in high-altitude deer mice. Journal of Experimental Biology 220, 3616-3620.

Tate, K. B., Wearing, O. H., Ivy, C. M., Cheviron, Z. A., Storz, J. F., McClelland, G. B. and Scott, G. R. (2020). Coordinated changes across the $O 2$ transport pathway underlie adaptive increases in thermogenic capacity in high-altitude deer mice. Proceedings of the Royal Society $B$ 287, 20192750.

Team, R. C. (2012). R: A Language and Environment for Statistical Computing. Vienna, Austria: R Foundation for Statistical Computing.

Warton, D. I., Duursma, R. A., Falster, D. S. and Taskinen, S. (2012). smatr 3- an R package for estimation and inference about allometric lines. Methods in Ecology and Evolution 3, 257-259. 


\section{=igure 2 Spinetails}
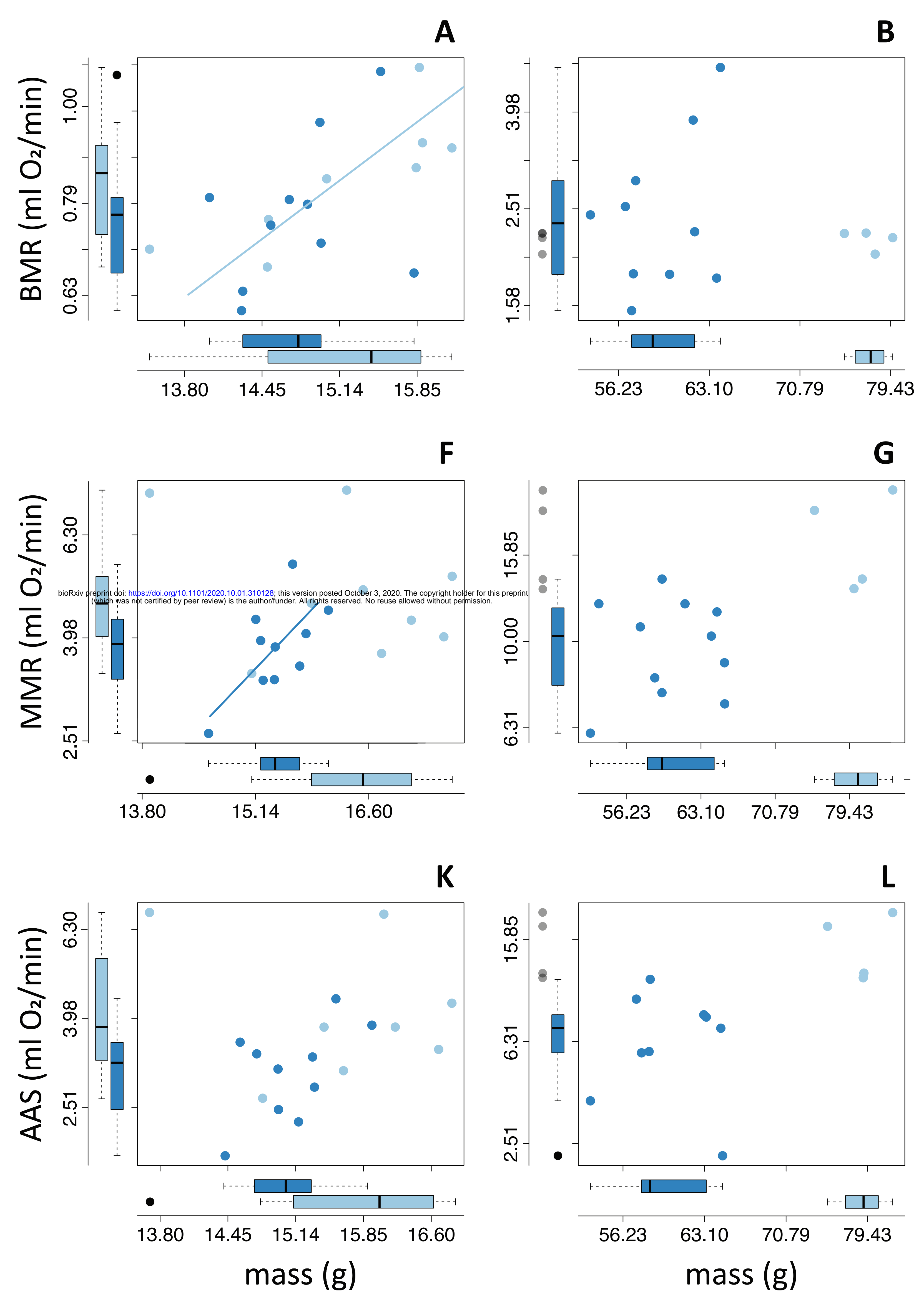

G

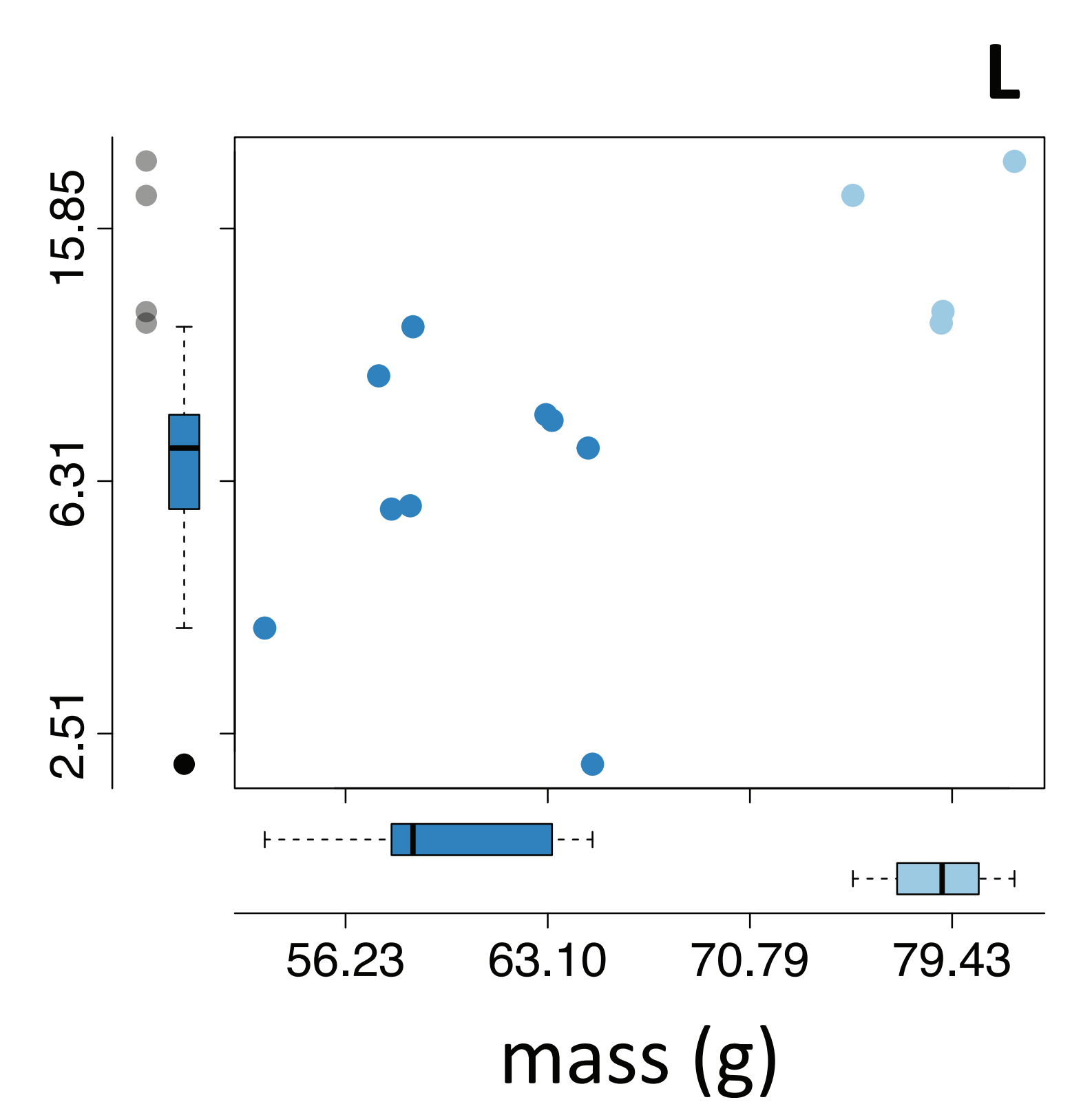

Wrens
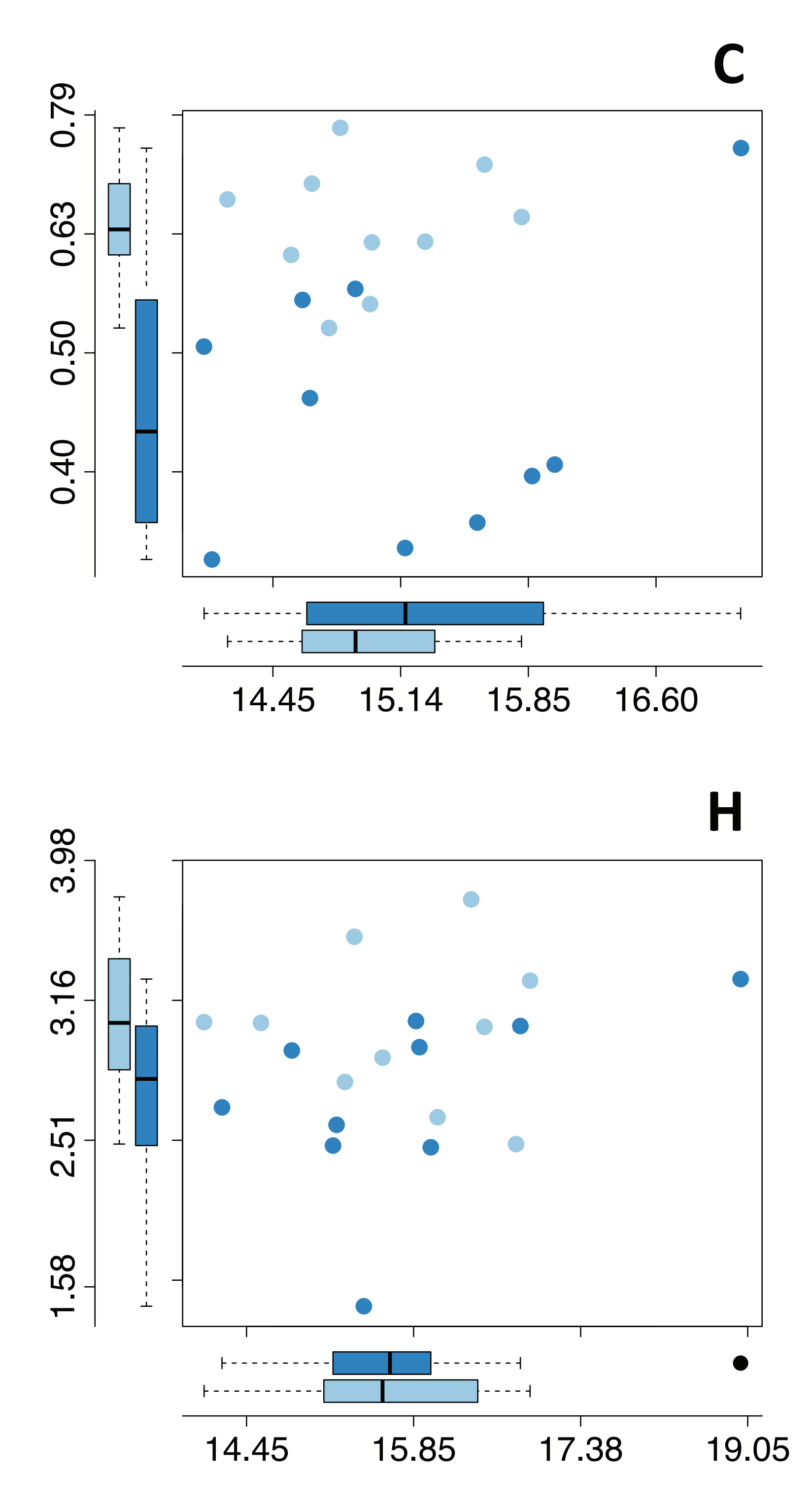

M

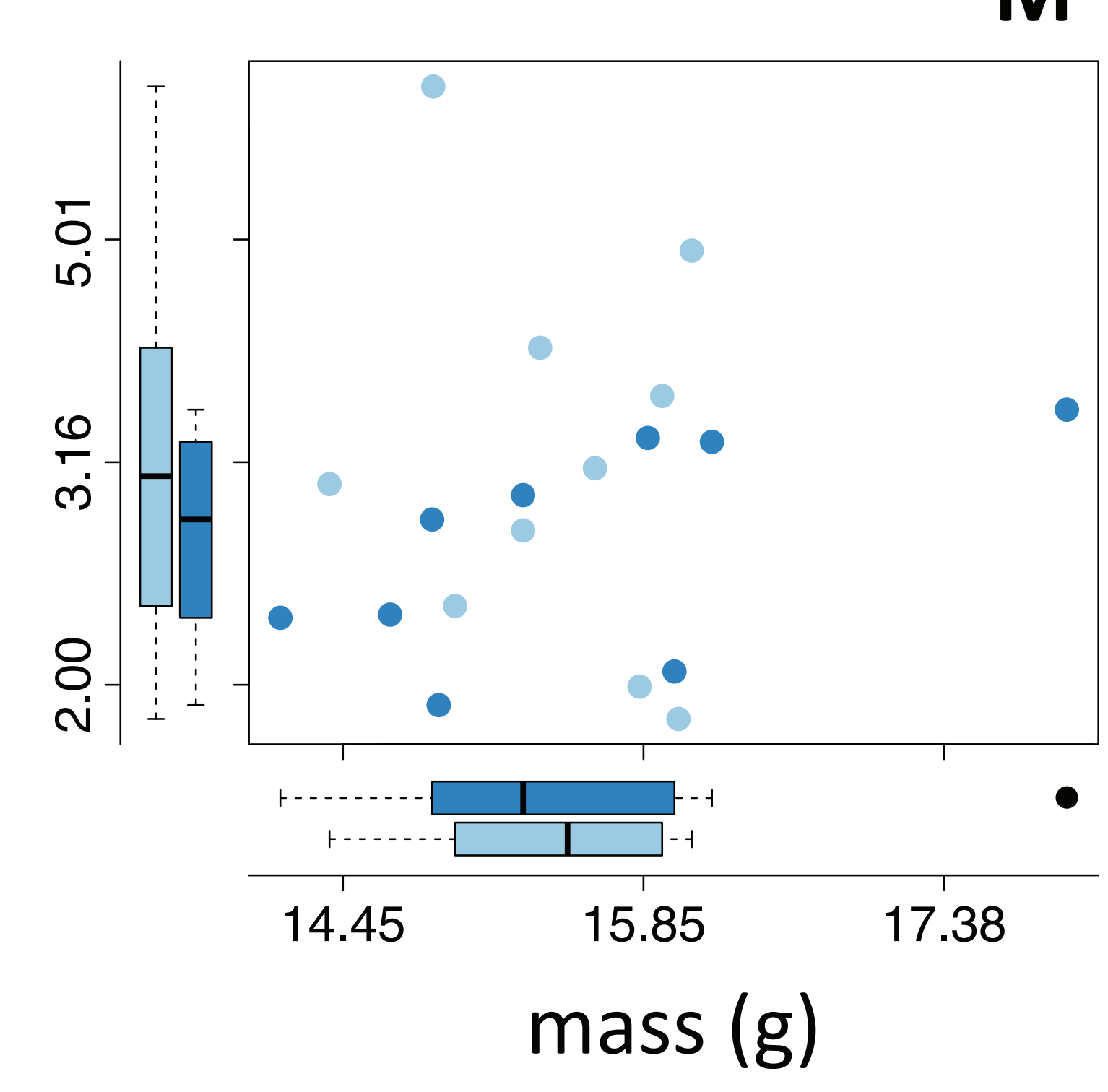

Tanagers
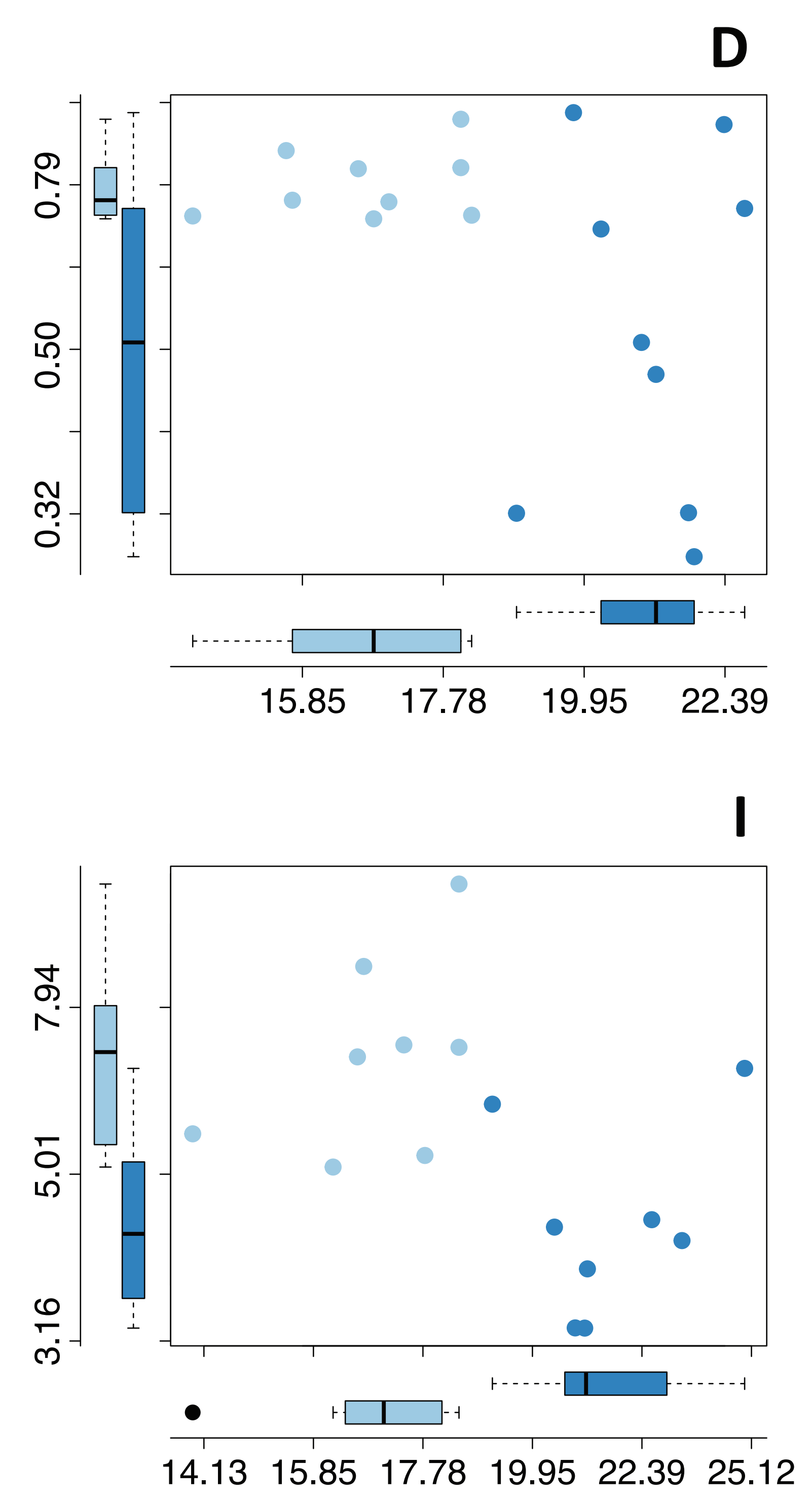

Warblers
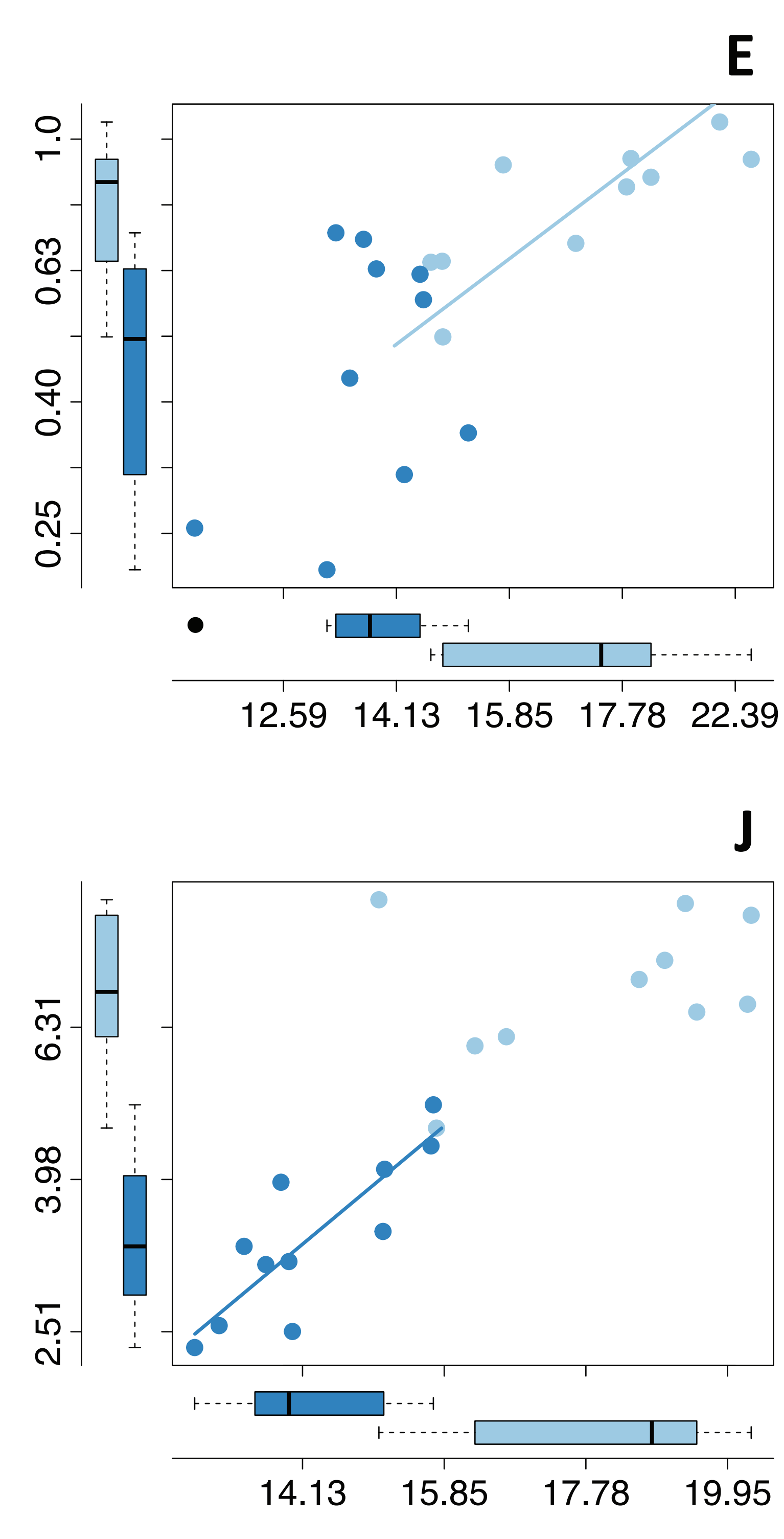

N

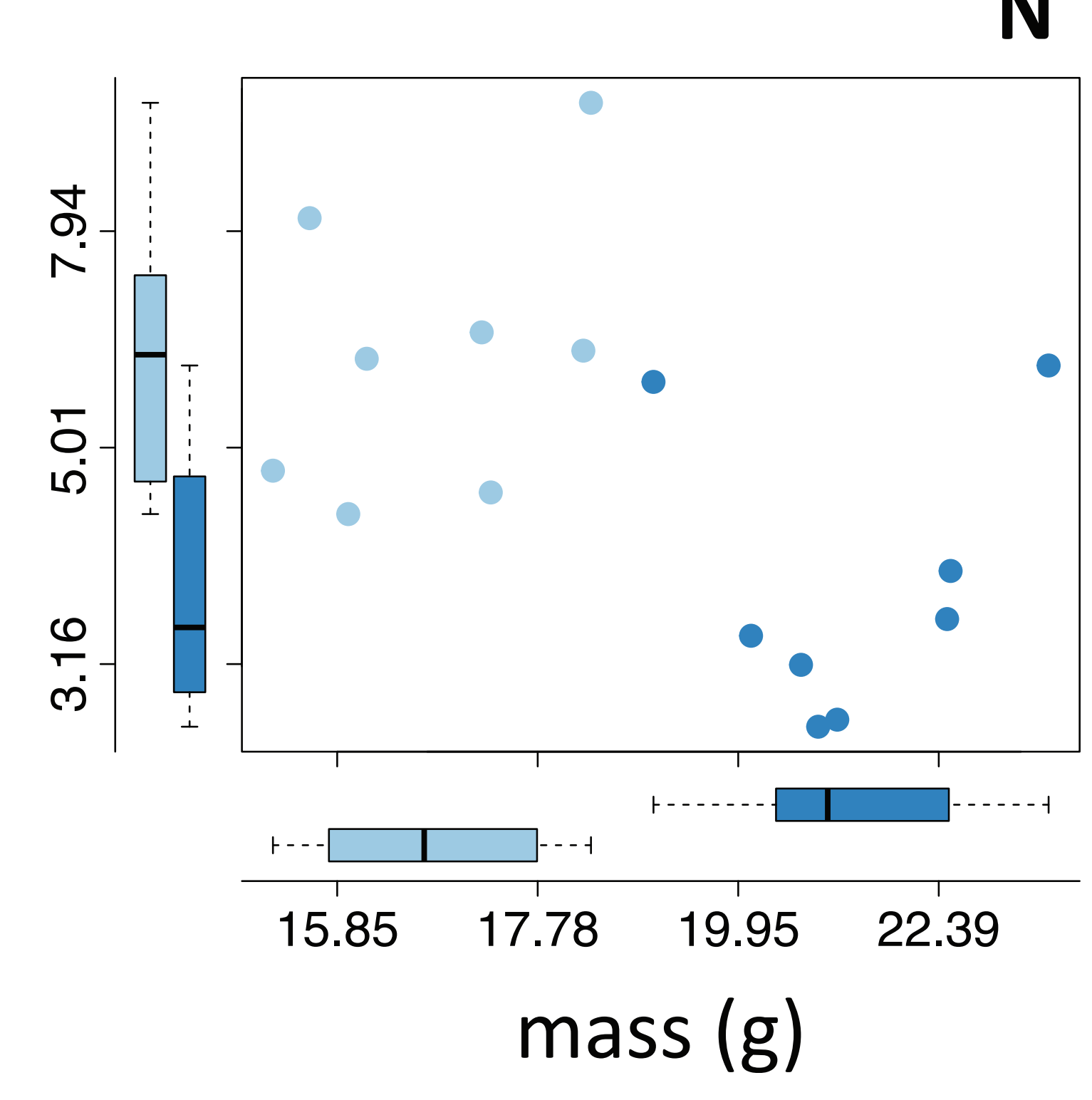

0

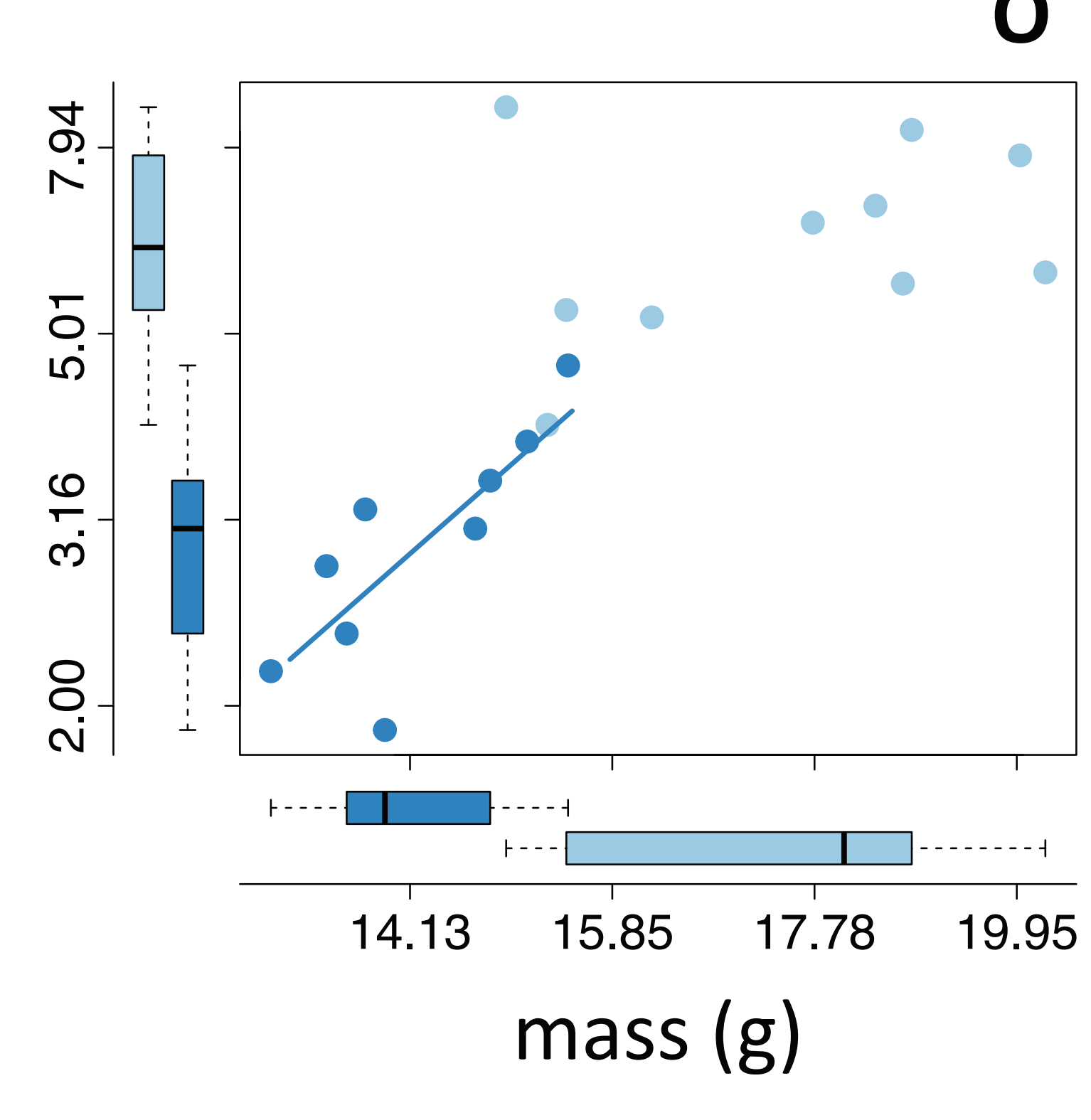




\section{Supplementary Tables}

Supplementary table 1. Information about geographical coordinates, elevation $(\mathrm{m})$, weather, and landscape matrix of the localities visited for this study. All localities visited are located in the Valle del Cauca department, Colombia. Annual mean temperature and precipitation were extracted from the WorldClim database (BIO1 and $\mathrm{BIO} 12$, respectively; Hijmans et al, 2005 ${ }^{a}$ ). Also included are the species captured in each site and the year(s) each locality was visited.

\begin{tabular}{|c|c|c|c|c|c|c|c|c|}
\hline Name & Coordinates & $\begin{array}{l}\text { Elevation } \\
\qquad(\mathrm{m})\end{array}$ & $\begin{array}{c}\text { Annual Mean } \\
\text { Temperature } \\
\left({ }^{\circ} \mathrm{C}\right)\end{array}$ & $\begin{array}{c}\text { Annual } \\
\text { precipitation } \\
\text { (mm) }\end{array}$ & $\begin{array}{l}\text { Ambient } \\
\text { pO2 (kPa) }\end{array}$ & Landscape matrix & Species captured & Years visited \\
\hline \multirow[t]{5}{*}{$\begin{array}{l}\text { Estación Biológica } \\
\text { Zygia-ICESI }\end{array}$} & $\begin{array}{l}3.442^{\circ} \mathrm{N} \\
76.662^{\circ} \mathrm{W}\end{array}$ & $2311-2553$ & 17.5 & 2260 & 15.6-16.1 & $\begin{array}{l}\text { Primary and } \\
\text { secondary forests }\end{array}$ & Synallaxis azarae & 2017-2019 \\
\hline & & & & & & & Turdus serranus & \\
\hline & & & & & & & $\begin{array}{l}\text { Henicorhina } \\
\text { leucophrys }\end{array}$ & \\
\hline & & & & & & & Tangara vassorii & \\
\hline & & & & & & & Myiothlypis coronata & \\
\hline \multirow[t]{2}{*}{ Alto Anchicayá } & $\begin{array}{c}3.576^{\circ} \mathrm{N} \\
76.880^{\circ} \mathrm{W}\end{array}$ & $525-889$ & 24.2 & 2093 & $19.2-20.0$ & $\begin{array}{l}\text { Primary forests } \\
\text { and road sides }\end{array}$ & $\begin{array}{l}\text { Henicorhina } \\
\text { leucosticta }\end{array}$ & 2017-2018 \\
\hline & & & & & & & $\begin{array}{l}\text { Myiothlypis } \\
\text { fulvicauda }\end{array}$ & \\
\hline \multirow[t]{2}{*}{ Universidad ICESI } & $\begin{array}{l}3.341^{\circ} \mathrm{N} \\
76.529^{\circ} \mathrm{W}\end{array}$ & 1014-1021 & 23.6 & 1490 & 18.9 & $\begin{array}{l}\text { Urban university } \\
\text { campus }\end{array}$ & Turdus ignobilis & 2017-2018 \\
\hline & & & & & & & Tangara vitriolina & \\
\hline $\begin{array}{l}\text { Ecoparque el } \\
\text { Embudo }\end{array}$ & $\begin{array}{l}3.345^{\circ} \mathrm{N} \\
76.553^{\circ} \mathrm{W}\end{array}$ & 1099 & 23.2 & 1557 & 18.7 & $\begin{array}{l}\text { Secondary forests } \\
\text { and cleared areas }\end{array}$ & Tangara vitriolina & 2019 \\
\hline Finca el Pasatiempo & $\begin{array}{c}4.677^{\circ} \mathrm{N} \\
75.739^{\circ} \mathrm{W}\end{array}$ & $1420-1445$ & 20.4 & 2251 & 17.9 & $\begin{array}{l}\text { Coffee farms and } \\
\text { road sides }\end{array}$ & Synallaxis albescens & 2019 \\
\hline Finca el Tabacal & $\begin{array}{l}4.681^{\circ} \mathrm{N} \\
75.764^{\circ} \mathrm{W}\end{array}$ & $1266-1276$ & 21.3 & 1973 & 18.3 & $\begin{array}{l}\text { Coffee farms and } \\
\text { road sides }\end{array}$ & Synallaxis albescens & 2019 \\
\hline Rural Alcala & $\begin{array}{c}4.676^{\circ} \mathrm{N} \\
75.772^{\circ} \mathrm{W}\end{array}$ & 1276 & 21.4 & 1927 & 18.3 & $\begin{array}{l}\text { Coffee farms and } \\
\text { road sides }\end{array}$ & Synallaxis albescens & 2019 \\
\hline
\end{tabular}


Finca Tipitapa

$4.662^{\circ} \mathrm{N}$,

$75.761^{\circ} \mathrm{W}$

$4.661^{\circ} \mathrm{N}$,

$75.754^{\circ} \mathrm{W}$
1334

1337
18.2

18.2
Coffee farms and

road sides

Synallaxis albescens

Coffee farms and road sides

${ }^{a}$ Hijmans, R. J., Cameron, S. E., Parra, J. L., Jones, P. G. and Jarvis, A. (2005). Very high resolution interpolated climate surfaces for global land areas. International Journal of Climatology 25, 1965-1978. 
Supplementary table 2. General information of the biology of the species selected for this study. We paired closely related species that had contrasting elevation ranges but were similar in terms of morphology, life history, and foraging ecology.

\begin{tabular}{|c|c|c|c|c|c|c|c|}
\hline Species & Size & Habitat & Diet & Foraging & Breeding & Behavior & Sources \\
\hline $\begin{array}{l}\text { Azara's Spinetail } \\
\text { Synallaxis azarae }\end{array}$ & $\begin{array}{l}15-18 \mathrm{~cm} \\
12-18 \mathrm{~g}\end{array}$ & $\begin{array}{l}\text { Dense undergrowth } \\
\text { of forest edges } \\
\text { secondary forest, } \\
\text { and overgrown } \\
\text { roadsides, usually } \\
\text { above } 1600 \mathrm{~m} \text {. }\end{array}$ & $\begin{array}{l}\text { Mostly arthropods, } \\
\text { occasionally small } \\
\text { seeds. }\end{array}$ & $\begin{array}{l}\text { Captures prey from } \\
\text { foliage, small } \\
\text { branches and dead } \\
\text { leaves, within 1-2 m } \\
\text { of ground. }\end{array}$ & $\begin{array}{l}\text { Throughout } \\
\text { the year in } \\
\text { Colombia. }\end{array}$ & $\begin{array}{l}\text { Sedentary and } \\
\text { teritorial, usually in } \\
\text { pairs, rarely joining } \\
\text { mixed species flocks. }\end{array}$ & $\begin{array}{l}\text { Hilty and Brown } \\
\text { (1986); Remsen } \\
(2020 a)\end{array}$ \\
\hline $\begin{array}{l}\text { Pale-breasted } \\
\text { Spinetail } \\
\text { Synallaxis albescens }\end{array}$ & $\begin{array}{l}13-16 \mathrm{~cm}, \\
9-17 \mathrm{~g} .\end{array}$ & $\begin{array}{l}\text { Open areas with } \\
\text { grassland, second } \\
\text { growth scrub and } \\
\text { overgrown } \\
\text { roadsides, usually } \\
\text { below } 1500 \mathrm{~m} \text {. }\end{array}$ & $\begin{array}{l}\text { Mostly } \\
\text { invertebrates. }\end{array}$ & $\begin{array}{l}\text { Captures prey from } \\
\text { foliage, grass and } \\
\text { small branches, } \\
\text { within } 1-2 \mathrm{~m} \text { of } \\
\text { ground. }\end{array}$ & $\begin{array}{l}\text { February to } \\
\text { November in } \\
\text { Colombia. }\end{array}$ & $\begin{array}{l}\text { Sedentary and } \\
\text { teritorial, usually in } \\
\text { pairs. }\end{array}$ & $\begin{array}{l}\text { Hilty and Brown } \\
\text { (1986); Remsen } \\
\text { (2020b) }\end{array}$ \\
\hline $\begin{array}{l}\text { Glossy-black Thrush } \\
\text { Turdus serranus }\end{array}$ & $\begin{array}{l}23-25 \mathrm{~cm} \\
70-90 \mathrm{~g}\end{array}$ & $\begin{array}{l}\text { Primary humid } \\
\text { montane forest, } \\
\text { forest borders, } \\
\text { occasionally in open } \\
\text { areas, mainly within } \\
1400 \text { to } 2800 \mathrm{~m} \text {. }\end{array}$ & Fruits and berries. & $\begin{array}{l}\text { Mainly forages } \\
\text { arboreally, } \\
\text { sometimes along } \\
\text { roads. }\end{array}$ & $\begin{array}{l}\text { March to } \\
\text { August in } \\
\text { Colombia. }\end{array}$ & $\begin{array}{l}\text { Sedentary, usually } \\
\text { single or in pairs, } \\
\text { may gather at } \\
\text { fruiting trees. Rarely } \\
\text { in mixed-species } \\
\text { flocks. }\end{array}$ & $\begin{array}{l}\text { Hilty and Brown } \\
(1986) ; \text { Collar } \\
(2020)\end{array}$ \\
\hline $\begin{array}{l}\text { Black-billed Thrush } \\
\text { Turdus ignobilis }\end{array}$ & $\begin{array}{l}18-24 \mathrm{~cm} \\
48-81 \mathrm{~g}\end{array}$ & $\begin{array}{l}\text { Semi-open to open } \\
\text { areas, forest } \\
\text { borders, mainly } \\
\text { witin } 900 \text { to } 2100 \\
\text { m. }\end{array}$ & $\begin{array}{l}\text { Mainly } \\
\text { invertebrates and } \\
\text { fruits, occasionally } \\
\text { seeds. }\end{array}$ & $\begin{array}{l}\text { Mainly forages } \\
\text { arboreally, also often } \\
\text { on ground, usually } \\
\text { near or in forests. }\end{array}$ & $\begin{array}{l}\text { December to } \\
\text { August in } \\
\text { Colombia. }\end{array}$ & $\begin{array}{l}\text { Sedentary, usually } \\
\text { single or in pairs, } \\
\text { may gather at } \\
\text { fruiting trees. }\end{array}$ & $\begin{array}{l}\text { Hilty and Brown } \\
\text { (1986); Collar et al } \\
\text { (2020) }\end{array}$ \\
\hline $\begin{array}{l}\text { Gray-breasted } \\
\text { Wood-wren } \\
\text { Henicorhina } \\
\text { leucophrys }\end{array}$ & $\begin{array}{l}10-11 \mathrm{~cm} \\
16-17 \mathrm{~g}\end{array}$ & $\begin{array}{l}\text { Undergrowth of } \\
\text { humid mountain } \\
\text { forest, usually } \\
\text { above } 1500 \mathrm{~m} \text {. }\end{array}$ & $\begin{array}{l}\text { Mostly } \\
\text { invertebrates. }\end{array}$ & $\begin{array}{l}\text { Captures prey in } \\
\text { dense vegetation, } \\
\text { usually below } 2 \mathrm{~m} .\end{array}$ & $\begin{array}{l}\text { December to } \\
\text { June in } \\
\text { Colombia. }\end{array}$ & $\begin{array}{l}\text { Sedentary and } \\
\text { teritorial, usually in } \\
\text { pairs. }\end{array}$ & $\begin{array}{l}\text { Hilty and Brown } \\
\text { (1986); Kroodsma } \\
\text { et al (2020) }\end{array}$ \\
\hline $\begin{array}{l}\text { White-breasted } \\
\text { Wood-wren } \\
\text { Henicorhina } \\
\text { leucosticta }\end{array}$ & $\begin{array}{l}10-11 \mathrm{~cm}, \\
15 \mathrm{~g} .\end{array}$ & $\begin{array}{l}\text { Undergrowth of wet } \\
\text { lowland forest, from } \\
\text { sea-level up to } 1300 \\
\text { m. }\end{array}$ & $\begin{array}{l}\text { Mostly } \\
\text { invertebrates. }\end{array}$ & $\begin{array}{l}\text { Captures prey in } \\
\text { tangles around fallen } \\
\text { trees and dense } \\
\text { vegetation, from the } \\
\text { ground up to } 2-3 \mathrm{~m} \text {. }\end{array}$ & $\begin{array}{l}\text { January to July } \\
\text { in most of its } \\
\text { range. }\end{array}$ & $\begin{array}{l}\text { Sedentary and } \\
\text { territorial, usually in } \\
\text { pairs, rarely joining } \\
\text { ant follower flocks. }\end{array}$ & $\begin{array}{l}\text { Hilty and Brown } \\
\text { (1986); Kroodsma } \\
\text { and Brewer (2020) }\end{array}$ \\
\hline
\end{tabular}




\begin{tabular}{|c|c|c|c|c|c|c|c|}
\hline $\begin{array}{l}\text { Blue-and-black } \\
\text { Tanager } \\
\text { Tangara vassorii }\end{array}$ & $\begin{array}{l}14-18 \mathrm{~cm} \\
15-21 \mathrm{~g}\end{array}$ & $\begin{array}{l}\text { Primary and } \\
\text { secondary humid } \\
\text { montane forest, and } \\
\text { forest borders, from } \\
1500 \text { to } 3500 \mathrm{~m} \text {. }\end{array}$ & $\begin{array}{l}\text { Mostly fruits and } \\
\text { some insects. }\end{array}$ & $\begin{array}{l}\text { Feeds in all forest } \\
\text { levels but prefers the } \\
\text { canopy, especially } \\
\text { around fruiting trees. }\end{array}$ & $\begin{array}{l}\text { February to } \\
\text { August in } \\
\text { Colombia. }\end{array}$ & $\begin{array}{l}\text { Very active, usually } \\
\text { seen in pairs or small } \\
\text { groups, and often } \\
\text { joins large mixed- } \\
\text { species flocks. }\end{array}$ & $\begin{array}{l}\text { Hilty and Brown } \\
\text { (1986); Bernabe } \\
\text { and Burns (2020) }\end{array}$ \\
\hline $\begin{array}{l}\text { Scrub Tanager } \\
\text { Stilpnia vitriolina }\end{array}$ & $\begin{array}{l}14 \mathrm{~cm} \\
18-26 \mathrm{~g}\end{array}$ & $\begin{array}{l}\text { Scrubby or open } \\
\text { areas with sparse } \\
\text { trees and bushes, } \\
\text { mostly between } 500 \\
\text { to } 2200 \mathrm{~m} \text {. }\end{array}$ & $\begin{array}{l}\text { Mostly fruits and } \\
\text { arthropods. }\end{array}$ & $\begin{array}{l}\text { Feeds in all forest } \\
\text { levels but prefers the } \\
\text { canopy, especially } \\
\text { around fruiting trees. }\end{array}$ & $\begin{array}{l}\text { Throughout } \\
\text { the year in } \\
\text { Colombia. }\end{array}$ & $\begin{array}{l}\text { Very active, usually } \\
\text { seen alone, in pairs } \\
\text { or small groups, } \\
\text { rarely found with } \\
\text { mixed-species flocks. }\end{array}$ & $\begin{array}{l}\text { Hilty and Brown } \\
\text { (1986); Hilty } \\
(2020)\end{array}$ \\
\hline $\begin{array}{l}\text { Russet-crowned } \\
\text { Warbler } \\
\text { Myiothlypis } \\
\text { coronata }\end{array}$ & $\begin{array}{l}14 \mathrm{~cm} \\
13-19 \mathrm{~g}\end{array}$ & $\begin{array}{l}\text { Humid montane } \\
\text { forests, forest } \\
\text { borders, and } \\
\text { secondary growth, } \\
\text { between } 1300 \text { to } \\
2500 \mathrm{~m} \text {. }\end{array}$ & $\begin{array}{l}\text { Mostly } \\
\text { invertebrates. }\end{array}$ & $\begin{array}{l}\text { Captures prey at low } \\
\text { to middle levels and } \\
\text { dense areas, mainly } \\
\text { at } 1 \text { to } 6 \mathrm{~m} \text { but can } \\
\text { be seen higher. }\end{array}$ & $\begin{array}{l}\text { May to June in } \\
\text { Colombia. }\end{array}$ & $\begin{array}{l}\text { Very active, usually } \\
\text { seen in pairs or small } \\
\text { groups, and often } \\
\text { joins mixed-species } \\
\text { flocks. }\end{array}$ & $\begin{array}{l}\text { Hilty and Brown } \\
\text { (1986); Curson } \\
\text { and Bonan (2020); } \\
\text { personal } \\
\text { observations }\end{array}$ \\
\hline $\begin{array}{l}\text { Buff-rumped } \\
\text { Warbler } \\
\text { Myiothlypis } \\
\text { fulvicauda }\end{array}$ & $\begin{array}{l}13 \mathrm{~cm}, \\
14 \mathrm{~g}\end{array}$ & $\begin{array}{l}\text { Primary and } \\
\text { secondary forest } \\
\text { areas, mostly } \\
\text { around water } \\
\text { bodies and forest } \\
\text { edges. Usually } \\
\text { below } 1000 \mathrm{~m} \text {. }\end{array}$ & $\begin{array}{l}\text { Mostly } \\
\text { invertebrates. }\end{array}$ & $\begin{array}{l}\text { Captures prey close } \\
\text { to the ground, along } \\
\text { stream edges and } \\
\text { damp areas, but can } \\
\text { be seen higher. }\end{array}$ & $\begin{array}{l}\text { February to } \\
\text { April in } \\
\text { Colombia. }\end{array}$ & $\begin{array}{l}\text { Very active, usually } \\
\text { seen in pairs. }\end{array}$ & $\begin{array}{l}\text { Hilty and Brown } \\
(1986) ; \text { Curson } \\
\text { (2020); personal } \\
\text { observations }\end{array}$ \\
\hline
\end{tabular}


Supplementary table 3. Average mass-corrected BMR, MMR, and aerobic scope values, standard deviations (SD) and sample size ( $\mathrm{n}$ ) for each species analyzed. Also shown, the percentage of change in the highland mass-corrected metabolic rates in relation to lowland (positive values indicate higher values in the highland species), the respective pairwise t-tests evaluating the difference in means, the size of the effect, and the power of each statistical comparison.

\begin{tabular}{|c|c|c|c|c|c|c|c|c|c|c|}
\hline & \multicolumn{3}{|c|}{ High elevation species } & \multicolumn{3}{|c|}{ Low elevation species } & \multirow[b]{2}{*}{$\begin{array}{c}\% \\
\text { change }\end{array}$} & \multirow{2}{*}{$\begin{array}{c}t \text {-test } \\
p \text {-value }\end{array}$} & \multicolumn{2}{|c|}{ Power analysis } \\
\hline & $\begin{array}{c}\text { Average } \\
\left(\mathrm{mlO}_{2} \mathrm{~min}^{-1} \mathrm{~g}^{-1}\right)\end{array}$ & SD & $n$ & $\begin{array}{c}\text { Average } \\
\left(\mathrm{mlO}_{2} \mathrm{~min}^{-1} \mathrm{~g}^{-1}\right)\end{array}$ & SD & $n$ & & & $\begin{array}{l}\text { effect size } \\
\text { (Hedges' } \\
\text { G) }\end{array}$ & power \\
\hline \multicolumn{11}{|l|}{ BMR } \\
\hline Spinetails & 0.135 & 0.018 & 8 & 0.127 & 0.023 & 10 & $6.3 \%$ & 0.4239 & 0.378 & 0.197 \\
\hline Thrushes & 0.114 & 0.006 & 4 & 0.162 & 0.062 & 10 & $-29.5 \%$ & 0.0383 & 0.888 & 0.619 \\
\hline Wrens & 0.107 & 0.016 & 11 & 0.074 & 0.019 & 10 & $44.4 \%$ & 0.0005 & 1.857 & 1.000 \\
\hline Tanagers & 0.119 & 0.011 & 9 & 0.074 & 0.034 & 9 & $60.4 \%$ & 0.0039 & 1.770 & 0.999 \\
\hline Warblers & 0.117 & 0.019 & 10 & 0.082 & 0.032 & 10 & $43.5 \%$ & 0.0085 & 1.357 & 0.987 \\
\hline \multicolumn{11}{|l|}{ MMR } \\
\hline Spinetails & 0.771 & 0.269 & 9 & 0.610 & 0.120 & 10 & $26.5 \%$ & 0.1265 & 0.789 & 0.658 \\
\hline Thrushes & 0.896 & 0.230 & 4 & 0.587 & 0.191 & 12 & $52.5 \%$ & 0.0661 & 1.540 & 0.988 \\
\hline Wrens & 0.637 & 0.241 & 11 & 0.430 & 0.155 & 11 & $48.1 \%$ & 0.0283 & 1.022 & 0.912 \\
\hline Tanagers & 0.974 & 0.339 & 9 & 0.563 & 0.152 & 8 & $73.1 \%$ & 0.0069 & 1.534 & 0.991 \\
\hline Warblers & 1.024 & 0.219 & 10 & 0.538 & 0.144 & 12 & $90.3 \%$ & 0.0000 & 2.674 & 1.000 \\
\hline \multicolumn{11}{|l|}{ AAS } \\
\hline Spinetails & 0.679 & 0.276 & 8 & 0.493 & 0.112 & 10 & $37.7 \%$ & 0.1071 & 0.926 & 0.770 \\
\hline Thrushes & 0.794 & 0.230 & 4 & 0.389 & 0.193 & 10 & $103.8 \%$ & 0.0283 & 1.989 & 0.999 \\
\hline Wrens & 0.542 & 0.244 & 10 & 0.398 & 0.109 & 10 & $36.3 \%$ & 0.1122 & 0.764 & 0.654 \\
\hline Tanagers & 0.865 & 0.351 & 9 & 0.491 & 0.161 & 8 & $76.1 \%$ & 0.0146 & 1.339 & 0.966 \\
\hline Warblers & 0.927 & 0.224 & 10 & 0.474 & 0.153 & 10 & $95.5 \%$ & 0.0001 & 2.363 & 1.000 \\
\hline
\end{tabular}


Supplementary table 4. Results of the linear mixed models that explained the variation in each metabolic parameter (logBMR, log MMR, and log AAS) as a function of elevation (fixed effect) and the interaction between species group and mass (random effects).

\begin{tabular}{|c|c|c|c|c|c|c|c|c|c|}
\hline \multirow[b]{2}{*}{ Predictors } & \multicolumn{3}{|c|}{ BMR } & \multicolumn{3}{|c|}{ MMR } & \multicolumn{3}{|c|}{ AAS } \\
\hline & Estimates & $\mathrm{Cl}$ & $p$ & Estimates & $\mathrm{Cl}$ & $p$ & Estimates & $\mathrm{Cl}$ & $p$ \\
\hline (Intercept) & -0.11 & $-0.19--0.04$ & 0.004 & 0.73 & $0.63-0.82$ & $<0.001$ & 0.65 & $0.56-0.73$ & $<0.001$ \\
\hline Elevation & -0.07 & $-0.13--0.01$ & 0.022 & -0.15 & $-0.20--0.10$ & $<0.001$ & -0.2 & $-0.26--0.13$ & $<0.001$ \\
\hline $\begin{array}{l}\text { Random } \\
\text { Effects }\end{array}$ & Variance & & & Variance & & & Variance & & \\
\hline Residuals & 0.02 & & & 0.01 & & & 0.02 & & \\
\hline Species group & 1.76 & & & 1.41 & & & 0.66 & & \\
\hline Mass & 1.16 & & & 0.95 & & & 0.49 & & \\
\hline Sample size & 90 & & & 90 & & & 84 & & \\
\hline $\begin{array}{l}\text { Marginal } R^{2} / \\
\text { Conditional } R^{2}\end{array}$ & 0.001 / 0.991 & & & 0.004 / 0.992 & & & 0.013 / 0.970 & & \\
\hline
\end{tabular}


Supplementary table 5. Results of the ANCOVA that explained the variation in each metabolic parameters (logBMR, log MMR, and log AAS) as a function of mass, and elevation per group.

\begin{tabular}{|c|c|c|c|c|c|c|c|c|c|}
\hline \multirow[b]{2}{*}{ Predictors } & \multicolumn{3}{|c|}{ BMR } & \multicolumn{3}{|c|}{ MMR } & \multicolumn{3}{|c|}{ AAS } \\
\hline & Estimates & $\mathrm{Cl}$ & $p$ & Estimates & $\mathrm{Cl}$ & $p$ & Estimates & $\mathrm{Cl}$ & $p$ \\
\hline (Intercept) & -0.53 & $-0.93--0.13$ & 0.009 & -0.04 & $-0.44-0.35$ & 0.837 & -0.23 & $-0.73-0.27$ & 0.362 \\
\hline Mass & 0.46 & $0.16-0.76$ & 0.003 & 0.77 & $0.48-1.06$ & $<0.001$ & 0.9 & $0.52-1.27$ & $<0.001$ \\
\hline Spinetails : elevation & -0.06 & $-0.13--0.00$ & 0.043 & -0.16 & $-0.22--0.09$ & $<0.001$ & -0.18 & $-0.26--0.10$ & $<0.001$ \\
\hline Thrushes : elevation & 0.04 & $-0.06-0.14$ & 0.38 & -0.17 & $-0.27--0.08$ & $<0.001$ & -0.29 & $-0.41--0.16$ & $<0.001$ \\
\hline Wrens : elevation & -0.18 & $-0.25--0.12$ & $<0.001$ & -0.23 & $-0.29--0.17$ & $<0.001$ & -0.23 & $-0.31--0.15$ & $<0.001$ \\
\hline Tanagers : elevation & -0.17 & $-0.23--0.11$ & $<0.001$ & -0.15 & $-0.21--0.09$ & $<0.001$ & -0.17 & $-0.25--0.09$ & $<0.001$ \\
\hline Warblers : elevation & -0.17 & $-0.23--0.10$ & $<0.001$ & -0.15 & $-0.21--0.08$ & $<0.001$ & -0.15 & $-0.23--0.07$ & 0.001 \\
\hline Observations & 90 & & & 91 & & & 85 & & \\
\hline$R^{2} / R^{2}$ adjusted & 0.799 / 0.784 & & & $0.741 / 0.723$ & & & $0.603 / 0.572$ & & \\
\hline
\end{tabular}

